\title{
Ameliorating Effects of Vitamin E and Selenium on Immunological Alterations Induced by Imidacloprid Chronic Toxicity in Chickens
}

\author{
Abdulwahab M. Kammon ${ }^{1,2 *}$, Rajinder S. Brar², Harmanjit S. Banga ${ }^{1}$ and Sandeep Sodhi ${ }^{1}$ \\ ${ }^{1}$ Department of Poultry and Fish Diseases, Faculty of Veterinary Medicine, Tripoli University, P.O. Box 13662, Tripoli-Libya \\ ${ }^{2}$ Department of Veterinary Pathology, College of Veterinary Science, Guru Angad Dev Veterinary and Animal Sciences University, Ludhiana-141004 (PB), India
}

\begin{abstract}
The purpose of the current study was to investigate the immunological impacts of chronic imidacloprid insecticide toxicity in broiler chickens and the protective effects of vitamin $E$ and selenium. Broiler chicks $(n=90)$ aged day old were randomly segregated into three groups of 30 chicks each and were kept in separate pens. Newcastle disease (ND) vaccine was given on day 7 and 28 of age. On day 8 , chicks in group I were administered $5 \mathrm{mg} / \mathrm{kg}$ bw $(1 / 20$ $\mathrm{LD}_{50}$ ) imidacloprid orally. Chicks in group II were given imidacloprid $5 \mathrm{mg} / \mathrm{kg}$ bw orally plus a mixture of vitamin $\mathrm{E}$ and selenium $\cong 200 \mathrm{mg} / \mathrm{kg}$ diet, while group III was given distilled water (DW) orally and served as a control. The treatments were given daily based on weekly body weight till day 45 . Antibody titration, serum total immunoglobulins, circulating immune complexes, cell-mediated immunity and histopathology of bursa of Fabricius and spleen were examined. Imidacloprid produced significant decline in the titer of antibodies against ND vaccine, total immunoglobulins and circulating immune complexes in imidacloprid treated group on day 45 as compared to control group. There were no significant changes in the skin thickness between treated chickens and chickens of control group. Histopathology of the bursa of Fabricius revealed edema, lymphocytic depletion in the medulla and cortex and mild interfollicular fibrosis in imidacloprid treated group. The spleen showed mild haemorrhages and lymphocytic depletion. Supplementation of vitamin $\mathrm{E}$ and selenium resulted in marked improvements in humoral immunity and pathology of lymphoid organs. It is concluded that imidacloprid insecticide has immunological deleterious effects in chickens targeting the humoral immune responses and vitamin $\mathrm{E}$ and selenium supplementation decreased the ill effects of imidacloprid.
\end{abstract}

Keywords: Imidacloprid; Chickens; Immunotoxicity; Vitamin E; Selenium

\section{Introduction}

Insecticides are being used extensively in the field of agriculture, veterinary medicine, and public health. The indiscriminate use of insecticides has led to a widespread concern over the potential adverse effects of these chemicals on human and animal health. There is ample evidence to suggest that the use of insecticides in crops, in storehouses, in poultry houses and livestock leaves behind its residue that may cause interference with some of the fundamental biological processes. Many cases of high mortality among poultry and other avian species are associated with acute exposure to insecticides [1-3].

Imidacloprid is the first representative of the neonicotinoid insecticides that was registered and is presently the most widely used insecticide worldwide. Imidacloprid is the insecticide with the world's fastest growing sales and is considered possible replacement for organophosphorus insecticides in agriculture $[4,5]$.

Few studies have examined the deleterious effects of Imidacloprid on vertebrate animals. The acute oral toxicity $\left(\mathrm{LD}_{50}\right)$ of imidacloprid is $31 \mathrm{mg} / \mathrm{kg}, 152 \mathrm{mg} / \mathrm{kg}$ and $25-50 \mathrm{mg} / \mathrm{kg}$ in Japanese quail, bobwhite quail and pigeon, respectively [4], while the acute oral $\mathrm{LD}_{50}$ of imidacloprid in chicken is $104.1 \mathrm{mg} / \mathrm{kg}$ bw [6]. However there is lack of information on chronic toxicity of imidacloprid in chickens. Among the sublethal effects of insecticides, immunotoxicity is important because immune system is the key for disease prevention in poultry. The immunotoxic effects of insecticides may include histopathologic effects in immune tissues and organs (bone marrow, thymus, spleen, and lymph nodes); cellular pathology, including abnormal proliferation of stem cells; altered maturation of immunocompetent cells; changes in $\mathrm{B}$ and $\mathrm{T}$ cell subpopulations; and functional alterations of immunocompetent cells, which are classified as altered humoral-mediated immunity, cell-mediated immunity, or nonspecific responses. Imidacloprid was found to be immunotoxic to rats inducing significant reduction of hemagglutination antibody titer, leukocytic migration inhibition and phagocytic indices [7]. Insecticides may affect the immune cells by production of free radicals. Antioxidants can increase immune responses by controlling the amount of free radicals generated by insecticides. Vitamin $\mathrm{E}$ and selenium functions as antioxidants in vivo as well as in vitro by scavenging active free radicals [8].

The present study was conducted to investigate the chronic immunological implications of imidacloprid in chickens and the role of vitamin $\mathrm{E}$ and selenium to modulate these implications.

\section{Materials and Methods}

\section{Experimental design}

Broiler chicks ( $\mathrm{n}=90)$ aged day old were randomly segregated into three groups of 30 chicks each and were kept in separate pens ( 30 chicks for each pen divided into 3 replicates of 10 chicks for each replicate). Chicks were acclimatized to the place for seven days before the experiment. On day 7, chicks in all groups were weighed and vaccinated against Newcastle disease (ND) using F1 strain (Venkys, Pune, India) by ocular route. On day 8 , chicks in group I were administered $1 / 20$ $\mathrm{LD}_{50}$ imidacloprid (5 $\mathrm{mg} / \mathrm{kg}$ bw mixed with water) orally. Chicks in

*Corresponding author: Abdulwahab M. Kammon, Department of Poultry and Fish Diseases, Faculty of Veterinary Medicine, Tripoli University, P.O. Box 13662, TripoliLibya, Tel: 00218914307212; E-mail: abd_kammon@yahoo.com

Received June 28, 2012; Accepted August 28, 2012; Published August 31, 2012

Citation: Kammon AM, Brar RS, Banga HS, Sodhi S (2012) Ameliorating Effects of Vitamin $E$ and Selenium on Immunological Alterations Induced by Imidacloprid Chronic Toxicity in Chickens. J Environ Anal Toxicol S4:007. doi:10.4172/21610525.S4-007

Copyright: (c) 2012 Kammon AM, et al. This is an open-access article distributed under the terms of the Creative Commons Attribution License, which permits unrestricted use, distribution, and reproduction in any medium, provided the original author and source are credited. 
Citation: Kammon AM, Brar RS, Banga HS, Sodhi S (2012) Ameliorating Effects of Vitamin E and Selenium on Immunological Alterations Induced by Imidacloprid Chronic Toxicity in Chickens. J Environ Anal Toxicol S4:007. doi:10.4172/2161-0525.S4-007

group II were given imidacloprid at the dose rate of $5 \mathrm{mg} / \mathrm{kg}$ bw by the same route as in group I plus a mixture of vitamin $\mathrm{E}$ and selenium (Micro Labs, Ltd., Banglore, India) at the dose rate of $200 \mathrm{mg} / \mathrm{kg}$ feed, while group III was given distilled water (DW) orally and served as a control for both the groups.

On day 21, eight chicks were randomly selected from each group and humanely euthanized for collection of blood and tissue samples.

On day 28, chickens of all groups were given a booster vaccination against ND using La Sota strain (Indovax Pvt Ltd, Hisar, Haryana, India) by intraocular route. At the end of the experiment on day 45 , remaining chickens from each group were humanely euthanized and representative blood and tissue samples were collected. The experiment was performed after getting the permission from Institutional Animal Ethics Committee, GADVASU, India.

\section{Immunological examinations}

The chronic effect of oral administration of imidacloprid (5 $\mathrm{mg} / \mathrm{kg} \mathrm{bw}$ ) on humoral immunity in broiler chickens was assessed by measuring serum antibodies against ND vaccine strain using haemagglutination inhibition (HI) test [9]. The results were expressed as $\log 2[10]$.

The chronic effect of oral administration of imidacloprid $(5 \mathrm{mg} / \mathrm{kg}$ bw) on cell-mediated immunity was assessed by contact hypersensitivity response of the chicken's skin to dinitrochlorobenzene (DNCB) [11]. The percentage of skin thickness increase was calculated as follows: Percentage of thickness increase $(\%)=[$ (skin thickness after challenge - skin thickness before challenge)/skin thickness before challenge] $\times$ 100 [12].

Total immunoglobulins and Circulating immune complexes were estimated in serum samples [13] and [14], respectively.

\section{Histopathology}

The detailed post mortem of chickens was conducted on day 21 and 45 and the representative tissue samples of bursa of Fabricius and spleen were collected in 10\% neutral formalin. After overnight washing in running water and dehydration in ascending grades of alcohol, the tissues were embedded in paraffin and $5 \mu \mathrm{m}$ thick sections were cut and stained with haematoxylin and eosin [15].

\section{Statistical analyses}

Data are expressed as means \pm SE. Analysis of variance (ANOVA), with Tukey HSD post hoc test was performed using the SPSS 11.5 computer program (SPSS Inc. Chicago, Illions, USA). P-values less than 0.05 were considered statistically significant.

\section{Results}

\section{Immunological examinations}

The effect of chronic oral administration of imidacloprid at the dose rate of $5 \mathrm{mg} / \mathrm{kg}$ bw on humoral immunity in broiler chickens and the protective effect of a mixture of vitamin $\mathrm{E}$ and selenium $\cong 200 \mathrm{mg} /$ $\mathrm{kg}$ feed are summarized in Table 1. Imidacloprid produced significant $(\mathrm{P}<0.05)$ decline in the titer of antibodies against $\mathrm{ND}$ vaccine from $8.25 \pm 0.42 \log 2$ in control group to $6.5 \pm 0.15 \log 2$ in imidacloprid treated group on day 45 . There was no significant difference between imidacloprid plus vitamin $\mathrm{E}$ and selenium group and control on day 45 , suggesting the protective role of vitamin $\mathrm{E}$ and selenium to enhance the response of immune system in the presence of insecticide's immune suppression.

The skin revealed infiltration of heterophils and mononuclear cells in dermis and hypodermis layers. There were no significant differences in the skin thickness between imidacloprid treated chickens (Figure 1A) and chickens of control group. However, skin thicknesses of chickens belong to imidacloprid plus vitamin $\mathrm{E}$ and selenium group was slightly increased but was not statistically significant (Figure 1B).

The results of daily oral administration of imidacloprid on serum total immunoglobulins and circulating immune complexes are presented in Table 2, which revealed significant changes on day 45. Serum levels of total immunoglobulins and circulating immune complexes were significantly decreased from $0.72 \pm 0.02 \mathrm{~g} / \mathrm{dl}$ in control chickens to $0.59 \pm 0.02 \mathrm{~g} / \mathrm{dl}$ in imidacloprid treated chickens and from $0.07 \pm 0.003 \mathrm{~g} / \mathrm{dl}$ in control to $0.04 \pm 0.006 \mathrm{~g} / \mathrm{dl}$ in imidacloprid treated chickens, respectively. There were no significant changes in serum total immunoglobulins and circulating immune complexes between chickens given imidacloprid plus vitamin $\mathrm{E}$ and selenium and chickens in control group indicating the protective role of vitamin $\mathrm{E}$ and selenium.

\begin{tabular}{|l} 
Groups \\
\hline Control (DW) \\
\hline Imidacloprid \\
\hline Imidacloprid + Vit E and Selenium \\
\hline
\end{tabular}

\begin{tabular}{|l|l|}
\multicolumn{2}{|c}{ HI antibody titer $(\log 2)$} \\
\hline Day $21(n=8)$ & Day $45(n=12)$ \\
\hline $7.37 \pm 0.49$ & $8.25 \pm 0.42 a b$ \\
\hline $5.75 \pm 0.25$ & $6.5 \pm 0.15 \mathrm{c}$ \\
\hline $7.00 \pm 0.59$ & $7.50 \pm 0.15 b$ \\
\hline
\end{tabular}

Values indicate mean \pm S.E

Means \pm S.E. within a column lacking a common superscript differ at $\mathrm{P}<0.05$

Table 1: Effect of chronic oral administration of imidacloprid $(5 \mathrm{mg} / \mathrm{kg}$ bw) on humoral immunity in broiler chickens on day 21 and 45 and the ameliorating effect of vitamin $\mathrm{E}$ and selenium (5 mg/kg bw $+200 \mathrm{mg} / \mathrm{kg}$ feed)

\begin{tabular}{|c|c|c|c|c|}
\hline \multirow{2}{*}{ Variable } & \multirow{2}{*}{ Day } & \multicolumn{3}{|r|}{ Groups } \\
\hline & & Control & Imidacloprid & Imidacloprid + Vitamin E \& Selenium \\
\hline \multirow{2}{*}{ Total immunoglobulins (g/dl) } & $21(n=8)$ & $0.70 \pm 0.06$ & $0.52 \pm 0.04$ & $0.63 \pm 0.04$ \\
\hline & $45(n=12)$ & $0.72 \pm 0.02 a$ & $0.59 \pm 0.02 b$ & $0.68 \pm 0.01 a$ \\
\hline \multirow{2}{*}{ Circulating immune complexes (g/dl) } & $21(n=8)$ & $0.07 \pm 0.005$ & $0.06 \pm 0.006$ & $0.07 \pm 0.006$ \\
\hline & $45(n=12)$ & $0.07 \pm 0.003 a$ & $0.04 \pm 0.006 b$ & $0.06 \pm 0.003 a$ \\
\hline
\end{tabular}

Values indicate mean \pm S.E

Means \pm S.E. within a row lacking a common superscript differ at $\mathrm{P}<0.05$

Table 2: Effect of chronic oral administration of imidacloprid (5 mg/kg bw) on total immunoglobulins and circulating immune complexes in broiler chickens on day 21 and 45 and supplementation vitamin $E$ and selenium $(5 \mathrm{mg} / \mathrm{kg} \mathrm{bw}+200 \mathrm{mg} / \mathrm{kg}$ feed). 
Citation: Kammon AM, Brar RS, Banga HS, Sodhi S (2012) Ameliorating Effects of Vitamin E and Selenium on Immunological Alterations Induced by Imidacloprid Chronic Toxicity in Chickens. J Environ Anal Toxicol S4:007. doi:10.4172/2161-0525.S4-007

\section{Histopathology of lymphoid organs}

Daily administration of Imidacloprid at the dose rate of $5 \mathrm{mg} / \mathrm{kg}$ bw produced edema and severe depletion of lymphoid cells in cortex and medulla of bursa of Fabricius, mild vacuolation in epithelial cells and mild interfollicular fibrosis on day 45 (Figure 2A). Spleen showed mild haemorrhage and lymphocytic depletion on day 45 (Figure $3 \mathrm{~A})$. However, chickens given imidacloprid plus vitamin $\mathrm{E}$ and selenium showed mild depletion of lymphoid cells in bursa (Figure 2B) and spleen (Figure 3B).

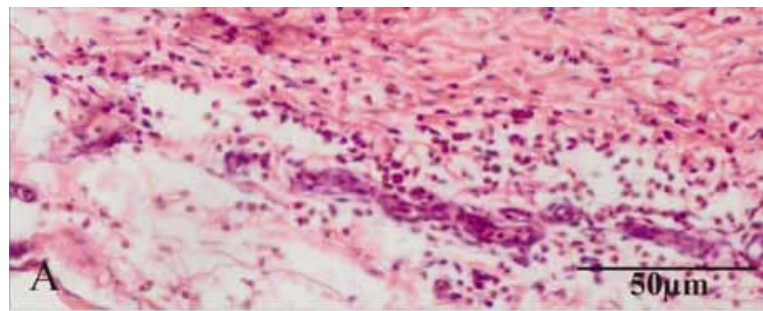

Figure 1A: Section of DNCB applied skin showing infiltration of heterophils and mononuclear cells in imidacloprid treated group at day $45 . \mathrm{H} \& \mathrm{E} \times 40$

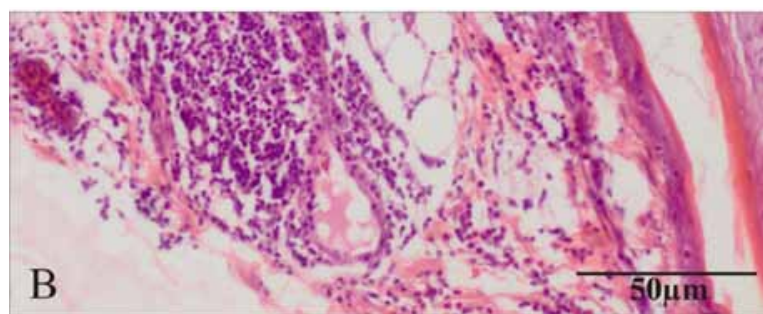

Figure 1B: Section of DNCB applied skin showing more extent of cellular infiltration in imidacloprid plus vitamin $E$ and selenium group at day 45 . H\&E $\times 40$

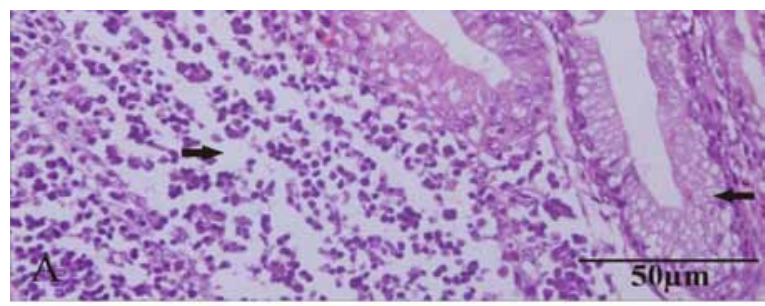

Figure 2A: Section of bursa of Fabricius in imidacloprid treated chicken showing severe depletion of lymphoid cells in cortex and medulla and mild vacuolation in epithelial cells (arrows) at day 45 . H\&E $\times 40$.

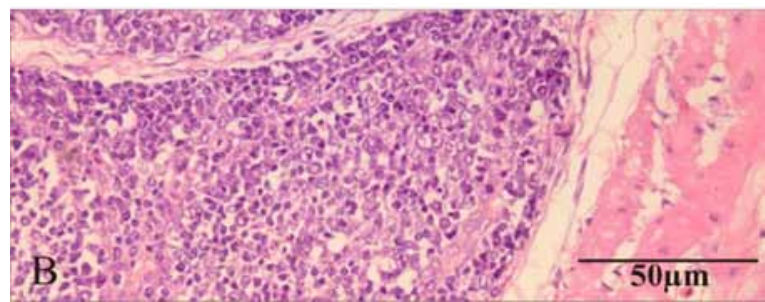

Figure 2B: Section of bursa of Fabricius in imidacloprid plus vitamin $E$ and selenium treated chicken showing mild depletion of lymphoid cells at day 45 . $\mathrm{H} \& \mathrm{E} \times 40$.

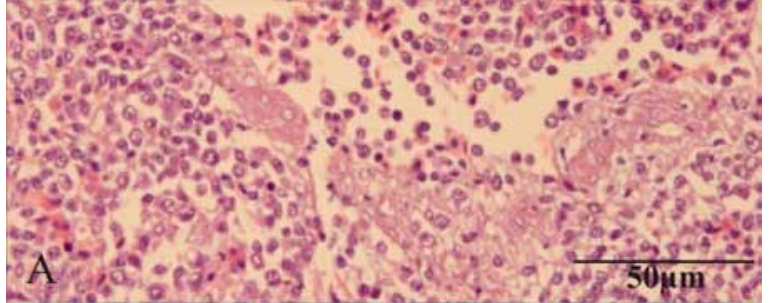

Figure 3A: Section of spleen in imidacloprid treated chicken showing mild haemorrhage and mild lymphocytic depletion at day 45 . H\&E $\times 40$

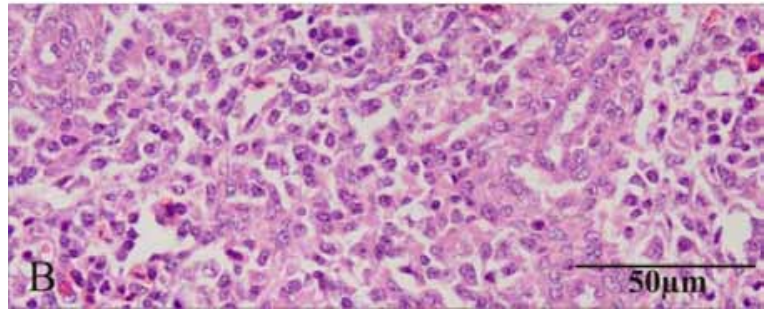

Figure 3B: Section of spleen in imidacloprid plus vitamin $E$ and selenium treated chicken showing mild lymphocytic depletion at day 45 . H\&E $\times 40$.

\section{Discussion}

The immune system integrity is the key to effectively preventing poultry diseases. Many poultry diseases are now controlled by properly planned biosecurity and vaccination. Immunosuppressive effects of xenobiotics are very important causes of vaccination failure thus predisposing animals to diseases. Alterations of the normal immune response can result in increased susceptibility to viral, bacterial, or parasitic infections [16].

Numerous studies reported immunotoxic effects of insecticides in different animal species [17-23].

Our data showed that daily administration of imidacloprid at the dose rate of $5 \mathrm{mg} / \mathrm{kg}$ bw is immunotoxic to chickens, altering mainly their humoral immunity measured by assessing the titer of antibodies against ND vaccine on day 45. Histopathological investigation of lymphoid organs showed some alterations in bursa of Fabricius and spleen. The lesions observed in bursa of Fabricius may explain the significant decline in antibodies measured against $\mathrm{ND}$ vaccine on day 45. Moreover, the serum levels of total immunoglobulins and circulating immune complexes were significantly declined on day 45 in chickens administered imidacloprid. There were no significant changes in the skin thickness between imidacloprid treated group, imidacloprid plus vitamin $\mathrm{E}$ and selenium group and control group. However, it is not clear whether the reason is due to compensatory responses. The presence of both enhanced and suppressed immune responses following exposure to pesticides suggests that the immune alterations are not a generalized cytotoxic effect and specific immunomodulation involving immuno-compensation may be present, although the extent, exact nature, and environmental significance of the compensating action are unknown [24].

Similarly significant progressive decrease in haemagglutinating antibody titer was reported in rats administered imidacloprid for 28 consecutive days [7]. The spleen exhibited depopulation of lymphocytes, mild fibrous tissue proliferation, thickening of capsule 
Citation: Kammon AM, Brar RS, Banga HS, Sodhi S (2012) Ameliorating Effects of Vitamin E and Selenium on Immunological Alterations Induced by Imidacloprid Chronic Toxicity in Chickens. J Environ Anal Toxicol S4:007. doi:10.4172/2161-0525.S4-007

and disintegration of white pulp and focal necrosis in all treated groups of rats as compared to control. The thymus showed mild congestion, depopulation of leukocytes, hemorrhages, edema and fibrous tissue proliferation. However, cell-mediated immunity which was assessed by subcutaneous administration of sheep red blood cells (SRBC) suspension into footpad showed insignificant difference between different groups of rats [7].

In a recent study, spleen tissues of the imidacloprid-treated rats displayed low numbers of lymphocytes and thymus tissues showed lymphocytic depletion with pyknotic nuclei [25].

In the present study, supplementation of vitamin $\mathrm{E}$ and selenium resulted in marked improvements in humoral immunity and pathology of lymphoid organs. This is in agreement with significant increase of antibody titres against SRBC antigen in growing Japanese quail fed two selenium supplemented diets $(0.5$ and $1.0 \mathrm{mg} / \mathrm{kg})$ suggesting that supplementing the diet with selenium has a beneficial effect on immune responses [26]. Moreover, significant decrease in the concentration of total immunoglobulins and circulating immune complexes in chicks following administration of malathion were successfully counteracted by a combination of vitamin $\mathrm{E}$ and selenium [22]. Addition of vitamin $\mathrm{E}$ and selenium to the poultry ration was found to significantly increase antibody titres (HI and ELISA) against ND Virus at 10 days post inoculation in broilers [27].

Antioxidants can increase immune responses by controlling the amount of free radicals generated by exposure to insecticides in a cell. Vitamin E functions as an antioxidant in vivo as well as in vitro by scavenging active free radicals. $\alpha$-Tochopherol is biologically the most active form of vitamin $\mathrm{E}$ and the major lipid-soluble antioxidant present in cells and blood [8]. Selenium activates an antioxidant enzyme called glutathione peroxidase. It forms selenocystine, part of the active site of glutathione peroxidase [28].

It is concluded that imidacloprid insecticide has immunological deleterious effects in chickens targeting the humoral immune responses with vitamin $\mathrm{E}$ and selenium supplementation decreasing the ill effects of imidacloprid. In view of the scarcity of data on imidacloprid immunotoxicity in poultry and other animals, the mechanism of action of imidacloprid on immune system is not known and needs to be elucidated. Thus further research may focus on the effect of imidacloprid on inhibition of non-target serine hydrolases, inhibition of esterases or production of cytokines etc.

\section{References}

1. Kawano Y, Bevenue A, Miyahara AY (1967) The effect of an accidental exposure of broiler chicks to dieldrin. Bulletin of Environmental Contamination and Toxicology 2: 12-24.

2. Bahl AK, Pomeroy BS (1978) Acute toxicity in poults associated with carbaryl insecticide. Avian Diseases 22: 526-528.

3. Aulakh RS, Bedi JS, Sharma JK (2005) Pesticide associated mortality in peacocks. Indian Veterinary Journal 82: 1112.

4. Kidd H, James D (1984) Agrochemicals Handbook. 400.

5. Jeschke P, Nauen R (2008) Neonicotinoids-from zero to hero in insecticide chemistry. Pest Management Science 64: 1084-1098.

6. Kammon AM, Brar RS, Banga HS, Sodhi S (2010) Patho-biochemical studies on hepatotoxicity and nephrotoxicity on exposure to chlorpyrifos and imidacloprid in layer chickens. Veterinarski Arhiv 80: 663-672.

7. Gatne MM, Ramesh, Bhoir PS, Deore MD (2006) Immunotoxicity studies of imidacloprid in rats. Toxicology International 13: 89-92.
8. Cheeseman KH, Burton GW, Ingold KU, Slater TF (1984) Lipid peroxidation and lipid antioxidants in normal and tumor cells. Toxicologic Pathology 12: 235239.

9. Allan WH, Gough RE (1974) A Standard Haemagglutination Inhibition Test fo Newcastle Disease. A comparison of Macro and Micro Methods. Veterinary Record 95: 120-123.

10. Brugh M (1978) A simple method for recording and analyzing serological data Avian Diseases 22: 362-365.

11. Tiwary BK, Goel MC (1985) Contact sensitivity to DNCB in normal and cellmediated-immunity deficient chickens: in vivo detection and correlation with lymphocyte transformation and graft-versus-host reaction. Veterinary Immunology and Immunopathology 8: 329-339.

12. Chowdhury SR, Smith TK, Boermans HJ, Woodward B (2005) Effects of feedborne Fusarium mycotoxins on hematology and immunology of turkeys. Poultry Science 84:1698-1706.

13. Oser BL (1965) Blood and other body fluids. In: Oser BL (ed) 1965. Hawks' Physiological Chemistry. 321-67. McGraw Hill Inc, New York, USA.

14. Creighton WD, Lambert PH, Miescher PA (1973) Detection of antibodies and soluble antigen-antibody complexes by precipitation with polyethylene glycol. Journal of Immunology 111: 1219-1227.

15. Luna LG (1968) Manual of Histological Staining Methods of Armed Forces Institute of Pathology. 3rd Edn. Mc Graw Hill book Co. New York.

16. Krzystyniak K, Tryphonas H, Fournier M (1995) Approaches to the evaluation of chemical-induced immunotoxicity. Environmental Health Perspectives 103 $17-22$

17. Prescott CA, Wilkie BN, Hunter B, Julian RJ (1982) Influence of a purified grade of pentachlorophenol on the immune response of chickens. American Journal of Veterinary Research 43: 481-487.

18. Stepanovic RM, Jokanovic M, Maksimovic M (1998) Toxicological importance of lymphocyte neuropathy target esterase. Achieves in Pharmacology 358: 5413.

19. Blakley B, Brousseau P, Fournier M, Voccia I (1999) Immunotoxicity of pesticides: a review. Toxicology and Industrial Health 15: 119-132.

20. Singh SP, Sharma LD, Chauhan RS (1999) Effect of single oral dose of alphamethrin on immune response of chicks. Journal of Immunology and Immunopathology 1: 63-66.

21. Handy RD, Abd-el Samei HA, Bayomy MFF, Mahran AM, Abdeen AM, et al. (2002) Chronic diazinon exposure: pathologies of spleen, thymus, blood cells and lymph nodes are modulated by dietary protein or lipid in the mouse. Toxicology 172: 13-34

22. Sodhi S, Sharma A, Brar RS (2006) A protective effect of vitamin E and selenium in ameliorating the immunotoxicity of malathion in chicks. Veterinary Research Communications 30: 935-942.

23. Kammon AM, Brar RS, Sodhi S, Banga HS, Nagra NS, et al. (2010) Ameliorating effect of vitamin $C$ on immunological implications induced by chronic chlorpyrifos toxicity in broilers. Libyan Veterinary Medical Journal 1 : 164-180.

24. Blakley B, Brousseau P, Fournier M, Voccia I (1999) Immunotoxicity of pesticides: a review. Toxicology and Industrial Health 15: 119-132.

25. Mohany M, Badr G, Refaat I, El-Feki M (2010) Immunological and histological effects of exposure to imidacloprid insecticide in male albino rats. African Journal of Pharmacy and Pharmacology 5: 2106-2114.

26. Biswas A, Mohan J, Sastry KVH (2006) Effect of higher levels of dietary selenium on production performance and immune responses in growing Japanese quail. British Poultry Science 47: 511-515

27. Swain BK, Johri TS, Majumdar S (2000) Effect of supplementation of vitamin $\mathrm{E}$, selenium and their different combinations on the performance and immune response of broilers. British Poultry Science 41: 287-292.

28. Niki (1996) a-A-tocopherol. In: Cadenas E and Packer L. (ed) 1996. Handbook of Antioxidants, pp 3-25. Marcel Dekker Inc, New York, USA. 